\title{
UNDERSTANDING WORK-LIFE CONFLICT AND ITS IMPLICATIONS
}

\author{
Jasmina Žnidaršǐ̌ \\ Faculty of Organizational Sciences in Kranj, University of Maribor, \\ Kranj, Slovenia \\ Miha Marič \\ Faculty of Organizational Sciences in Kranj, University of Maribor, \\ Kranj, Slovenia
}

\begin{abstract}
The present time is characterized by high level of competitiveness on the market, the rise of modern information technology, the demands for constant readiness of employees, and long working hours. One of the substantial demographic transformations involves the aging of the workforce. Numerous authors have demonstrated the link between gender and work-life conflict, but only a few researchers have examined how workers experience and manage conflict between their work and home lives across the lifespan. The current study aimed to bridge this gap and examined work-life conflict for individuals aged 30 to 72, focusing on how work-life conflict changes with age. The results show curvilinearity between age in years and work-life conflict. The negative value of the quadratic value coefficient shows a downward concave curve, which confirms curvilinearity and can be interpreted as: the older one is, the less work-life conflict is present - the drop begins after 51 years of age. The results of this study give better insights into the age effect on work-life conflict among higher education lecturers. The implications are foremost for the policymakers, higher education lecturers themselves, and work-life conflict researchers. Results of this study can be used both for further research and in practice. The broad scientific and professional interest in the constructs relating to work-life conflict is growing as global competition increases rapidly, and management expresses the need for such research; work-life conflict plays a remarkable role in the sustainability of organizations through their employees.
\end{abstract}

Keywords: work-life conflict, human resource management - HRM, organization, management

JEL classification: 01, 015

\footnotetext{
*miha.maric@um.si
} 


\section{RAZUMEVANJE KONFLIKTA IZMEĐU POSLOVNOG I PRIVATNOG ŽIVOTA I NJEGOVE IMPLIKACIJE}

Sažetak: Sadašnjost karakteriše visok nivo tržišne konkurentnosti, uspon modernih informacionih tehnologija, tražnja za konstantno spremnom radnom snagom $i$ dugotrajno radno vreme. Jedna od najvažnijih demografskih promena se odnosi na starenje radne snage. Brojni autori su utvrdili postojanje povezanosti između pola $i$ poslovno/privatnog konflikta, ali je svega nekoliko istraživača ispitalo način na koji zaposleni doživljavaju konflikt između njihovog poslovnog i porodičnog života i kako upravljaju njime tokom svog životnog veka. Cilj ove studije jeste da se premosti jaz $i$ istraži konflikt između poslovnog i privatnog života na primeru pojedinaca starosti od 30 do 72 godine, sa posebnim fokusom na to kako se pomenuti konflikt menja tokom godina. Rezultati ukazuju na postojanje povezanosti, prikazane linearnom krivom, između starosti izražene u godinama i poslovno/privatnog konflikta. Negativna vrednost regresionog koeficijenta u slučaju kvadratne regresije ukazuje na udubljenu, konkavnu krivu, što potvrđuje pomenutu povezanost i ukazuje na to da je kod starijih osoba ovaj konflikt manje prisutan i da pad nastupa nakon navršene 51. godine života. Rezultati ove studije pružaju bolji pogled na uticaj starosti na konflikt između poslovnog $i$ privatnog života predavača u visokom obrazovanju. Koristi mogu imati kreatori politika, sami predavači u visokom obrazovanje, kao i istraživači ovog konflikta. Rezultati istraživanja ove studije se mogu dvojako koristiti, u budućim istraživanjima i u praksi. Rasprostranjeno naučno i profesionalno interesovanje za činioce konflikta između poslovnog $i$ privatnog života raste uporedo sa naglim rastom globalne konkurencije, te menadžment iskazuje potrebu za ovakvim istraživanjima; konflikt između privatnog i poslovnog života igra veoma značajnu ulogu u postizanju održivosti organizacija posredstvom njihovih zaposlenih.

Ključne reči: poslovno/privatni konflikt, upravljanje ljudskim resursima, organizacija, upravljanje

\section{INTRODUCTION}

The present time is characterized by high competitiveness on the market and the rise of modern information technology as well as the demand for constant readiness of employees and long working hours. On the other hand, there are more and more families in which both parents work. So, workers face more and more difficulties in balancing work and family obligations. The lack of time, capacity or energy of the individual leads to the so-called work-life conflict, which has many negative consequences.

Work-life conflicts arise when work and family are incompatible (Cooklin, Dinh, Strazdins, Westrupp, Leach \& Nicholson, 2016; Netemeyer, Boles \& McMurrian, 1996) and are roughly divided into conflicts of time, strain and 
behavior (Greenhaus \& Beutell, 1985). The broad academic and professional interest in the constructs related to work-life conflicts is growing as global competition increases rapidly and management expresses the need for such research; work-life conflicts play a remarkable role in the sustainability of organizations through their employees.

This paper will present definitions of work-life conflict, the factors that influence the conflict between work and family, and the main consequences of the conflict between work and life. Based on studied literature and previous research, we propose an inquiry into the relationship between age and work-life conflict to determine whether the relationship is linear or curvilinear and explain how work-life conflict changes with age.

\section{WORK-LIFE CONFLICT}

The work-life conflict is an essential precursor of work-life balance (Bauld, Brough \& Timms, 2009) and has recently become the subject of much discussion in organizational behavior (Netemeyer, Boles \& McMurrian, 1996). The work-life conflict occurs when work and family issues are incompatible (Cooklin et al., 2016). According to Greenhaus and Beutell (1981), it occurs when the time devoted to the demands of one role makes it difficult to meet the demands of another role, or when the strain of one role makes it difficult to meet the demands of another role, and when the specific behaviors required of one role make it challenging to meet the demands of another role. Role requirements refer to the responsibilities, demands, expectations, duties, and obligations that an individual role entails (Netemeyer, Boles, \& McMurrian, 1996).

The literature, therefore, refers to two types of conflict: time conflict and strain conflict. A time conflict arises when the time devoted to the role of work interferes with the functioning and fulfillment of the family duties and vice versa. In particular, excessive time conflicts at work (family) can occur, making it difficult to fulfill family (work) duties. A strain conflict arises when stress from work (family) hinders family (work) duties. Netemeyer, Boles and McMurrian (1996), for example, highlight a case in which work-related irritability and anxiety hinder the fulfillment of family (work) duties and vice versa.

The work-life conflict often leads to negative consequences for individuals and organizations (Karabay, Akyüz \& Elçi, 2016). In theory, there are two conflicts between the two spheres, the conflict between work and family and the conflict between family and work. The conflict between work and family is a form of role conflict in which the demands of work and the time devoted to work 
influence and disrupt the fulfillment of family obligations. On the other hand, a work-life conflict is a form of role conflict in which the general demands of work and the time devoted to work influence and disrupt work performance (Netemeyer, Boles \& McMurrian, 1996).

In other words, this means that work can interfere with family affairs and thus affect the ordinary and necessary functioning of the individual, or conversely, family matters interfere with the functioning of the individual at work (Sav, Harris \& Sebar, 2013). The two conflicts are linked (Frone, Russel \& Cooper, 1992). The work-family conflict is perceived as more problematic than the family-work conflict, partly because the conflict between work and family is more frequent than the conflict between family and work (Turliuc \& Buliga, 2014).

A study among teachers (Erdamar \& Demirel, 2014) showed that the most common conflicts within the work-life conflict are continuing trouble at home confronted at work, the physical and mental fatigue at work makes difficult the responsibilities at home, a problem that one faces at work causes tension and stress at home. On the other hand, the most common problems within the family-work conflict are the responsibilities and small works at home causes to make sacrifice from sleeping. The unexpected situations at home (becoming ill of the child or unplanned guest) made the working life difficult.

\subsection{ANTECEDENTS OF WORK-LIFE CONFLICT}

The antecedents affecting work-life conflict are varied. According to the metaanalytical overview of studies on work-life conflict conducted by Michel, Kotrba, Mitchelson, Clark and Baltes (2011), the most important antecedents of work-life conflicts are stressors of the work role, the involvement of the work role, social support at work, work characteristics and the personality of the employee. Similarly, Ryan, Ma, Hsiao and $\mathrm{Ku}$ (2015) argued that the most important antecedents of work-life conflict are the work schedule (primarily work at weekends), conflicts between different roles and role ambiguity. Other studies have shown similar results. For example, that the work-life conflict mainly affects work overload (Goh, Ilies \& Wilson, 2015), working hours (Devi \& Rani, 2016), a poor working environment and poor role congruence as stressors (Karabay, Akyüz \& Elçi, 2016). Management support and satisfaction with the childcare organization are closely linked to minor conflicts between work and family (Goff, Mount \& Jamison, 1990).

On the other hand, Mauno, Ruokolainen and Kinnunen (2015) stress psychosocial factors as an essential precursor of the work-life conflict. Gender is also relevant, as the conflict between work and family generally places a more significant burden on women than men (Oshio, Inoue \& Tsutsumi, 2017). 
Research (Devi \& Rani, 2016) also showed that married women experienced more conflicts between work and family than unmarried women.

A hostile working environment reinforces the conflict between work and family (Shen, McCaughtry, Martin \& Garn, 2015, Jiang \& Shen, 2015) and has many negative consequences for the individual and the organization. However, it must be emphasized that both the support for the work environment and support for the social environment (partner, immediate social environment) are essential in reducing the work-life conflict (Griggs, Casper \& Eby, 2013).

Another important factor influencing work-life conflict is age (Dartey-Baah, 2015; Shankar, Mahesh \& Nanjundeswaraswamy, 2007). Research on conflicts between work and family life has mostly focused on younger workers, usually with young children, with little attention paid to workers throughout their lives. One of the rare studies that examined how conflicts between work and family change over the life span (Huffman, Culbertson, Henning \& Goh, 2013) showed a curvilinear relationship with the youngest and oldest workers had the fewest conflicting demands between work and home. The authors also argued that the age of the youngest child helps explain why these workers are less likely to have family conflicts with work.

\subsection{CONSEQUENCES OF WORK-LIFE CONFLICT}

Work-life conflicts have many consequences (Bauld, Brough \& Timms, 2009; Haar, 2009). Work-life conflict hurts an individual's job satisfaction (Wan Rashid, Sahari Nordin, Omar \& Ismail, 2012; Devi \& Rani, 2016; Turliuc \& Buliga, 2014. People who work in a family-friendly work environment that supports conflict reduction between work and family will be more satisfied with their work and vice versa (Zhao, Qu \& Ghiselli, 2011). Furthermore, the conflict between work and family has a significant impact on the life satisfaction of individuals (Goh, Ilies \& Wilson, 2015, Turliuc \& Buliga, 2014).

A minor conflict between work and life is important for an individual's mental health and subjective general well-being (Oshio et al., 2017). The conflict between work and family often has negative effects on the mental health of the individual. Research (Cooklin et al., 2016) also showed that the worker's health improved when the conflict between work and family life decreased. Which causes of conflict between work and family are more important and to what extent they have an impact also depends on gender. The survey also showed a negative correlation between the conflict between work and family and individual self-esteem (Wan Rashid et al., 2012).

The conflict between work and family can also play an important role as a mediator between different variables. For example, the results of research by 
Minnotte, Gravelle and Minnotte (2013) show that conflicts between work and family play the role of mediator between two characteristics of work, namely pressure at work and support from managers and psychological stress. The conflict between work and family can also serve as a mediator between life satisfaction and job satisfaction (Qu \& Zhao, 2012).

\section{METHODOLOGY}

\subsection{INQUIRY}

We propose an inquiry into the relationship between age and work-life conflict to determine whether the relationship is linear or curvilinear. At the beginning of the next chapter, we present the data gathering process and the sample properties and then continue with the results of the current study, which we later discuss and interpret.

\subsection{PARTICIPANTS}

We obtained data via an online questionnaire, to which the link was sent via email in winter 2018. Convenience sampling was used, as it is the most common (Etikan, Abubakar Musa, and Sunusi Alkassim, 2016), where people from six countries were invited to participate in our survey. First, the primary data was controlled and edited, then we used IBM SPSS Statistics 27 for processing and analyzing data.

A total of 148 online participants completed full sets of questionnaires, all of which were higher education lecturers, of whom 60 (40.5\%) were men, 84 $(56.8 \%)$ were women and four $(2.7 \%)$ did not give their answer. The average age of respondents was 38.24 years. On average, they had 19.13 years of work experience overall, of which 15.34 were in higher education.

According to the educational level of respondents: 3 (2.0\%) were with B.Sc. or B.A., $27(18.2 \%)$ were with M.Sc. or MBA and $113(76.4 \%)$ had a Ph.D. According to their academic rank: $21(14.2 \%)$ were teaching assistants, 14 (9.5\%) were research assistants, 52 (35.1\%) were assistant professors, 31 (20.9) were associate professors and $25(16.9 \%)$ were full professors.

\subsection{INSTRUMENTS}

Work-life conflict can be measured by using The Work-life conflict survey, a 16 item scale developed by Bohen and Viveros-Long (1981). The response scale is a five-point Likert scale ranging from 1 (completely disagree) to 5 (completely agree). Descriptive statistics for the variables constructing worklife conflict are presented in Table 1. 
Table 1

Descriptive statistics for work-life conflict

\begin{tabular}{|l|c|c|}
\hline & Mean & $\begin{array}{c}\text { Standard } \\
\text { Deviation }\end{array}$ \\
\hline My job keeps me away from my family too much. & 2,8716 & 1,28455 \\
\hline I feel I have more to do, than I can handle comfortably. & 3,6689 & 1,24206 \\
\hline $\begin{array}{l}\text { I have a good balance between my job and my family } \\
\text { time. }\end{array}$ & 3,0068 & 1,20935 \\
\hline I wish I had more time to do things for my family. & 3,8446 & 1,17057 \\
\hline I feel physically drained when I get home from work. & 3,2365 & 1,21421 \\
\hline Ifeel emotionally drained when I get home from work. & 3,1284 & 1,25237 \\
\hline Ifeel I have to rush to get everything done each day. & 3,5473 & 1,20844 \\
\hline $\begin{array}{l}\text { My time off from work does not match other family } \\
\text { members' schedules well. }\end{array}$ & 2,8514 & 1,18014 \\
\hline I feel I don't have enough time for myself. & 3,7635 & 1,18012 \\
\hline $\begin{array}{l}\text { I worry that other people at work think my family } \\
\text { interferes with my job. }\end{array}$ & 2,1149 & 1,24280 \\
\hline $\begin{array}{l}\text { I worry whether I should work less and spend more time } \\
\text { with my children. }\end{array}$ & 2,9122 & 1,31929 \\
\hline I find enough time for the children. & 3,0878 & 1,25589 \\
\hline I worry about how my kids are when I'm working. & 2,7432 & 1,21846 \\
\hline $\begin{array}{l}\text { I am comfortable with the arrangements for my children } \\
\text { while I am working. }\end{array}$ & 3,4932 & 1,12786 \\
\hline $\begin{array}{l}\text { Making arrangements for my children while I work } \\
\text { involves a lot of effort. }\end{array}$ & 2,8581 & 1,27781 \\
\hline $\begin{array}{l}\text { I worry that other people feel I should spend more time } \\
\text { with my children. }\end{array}$ & 2,3919 & 1,23792 \\
\hline Nor Au'
\end{tabular}

Note. Authors' calculations. 


\section{RESULTS}

We inquire into the relationship between age in years and work-life conflict. For this purpose, we have calculated regressions, in which age in years and its quadratic value are the independent variables, whereas work-life conflict is the dependent variable.

Table 2

Model Summary and Parameter Estimates for Work-Life Conflict

\begin{tabular}{|c|c|c|c|c|c|c|c|c|}
\hline \multirow{2}{*}{ Equation } & \multicolumn{4}{|c|}{ Model Summary } & \multicolumn{3}{c|}{ Parameter Estimates } \\
\cline { 2 - 10 } & $R$ Square & $F$ & $d f 1$ & $d f 2$ & Sig. & Constant & b1 & b2 \\
\hline Linear &, 019 & 2,672 & 1 & 141 &, 104 & 3,426 &,- 007 & \\
\hline Quadratic &, 034 & 2,435 & 2 & 140 &, 091 & 2,078 &, 051 &,- 001 \\
\hline
\end{tabular}

Note. Authors' calculations.

Table 2 and Figure 1 present the linear and quadratic regression models, which present the relations between age in years and work-life conflict based on the data collected among higher education lecturers. What happens when the independent variables age in years and its quadratic value affect the dependent variable of work-life conflict?

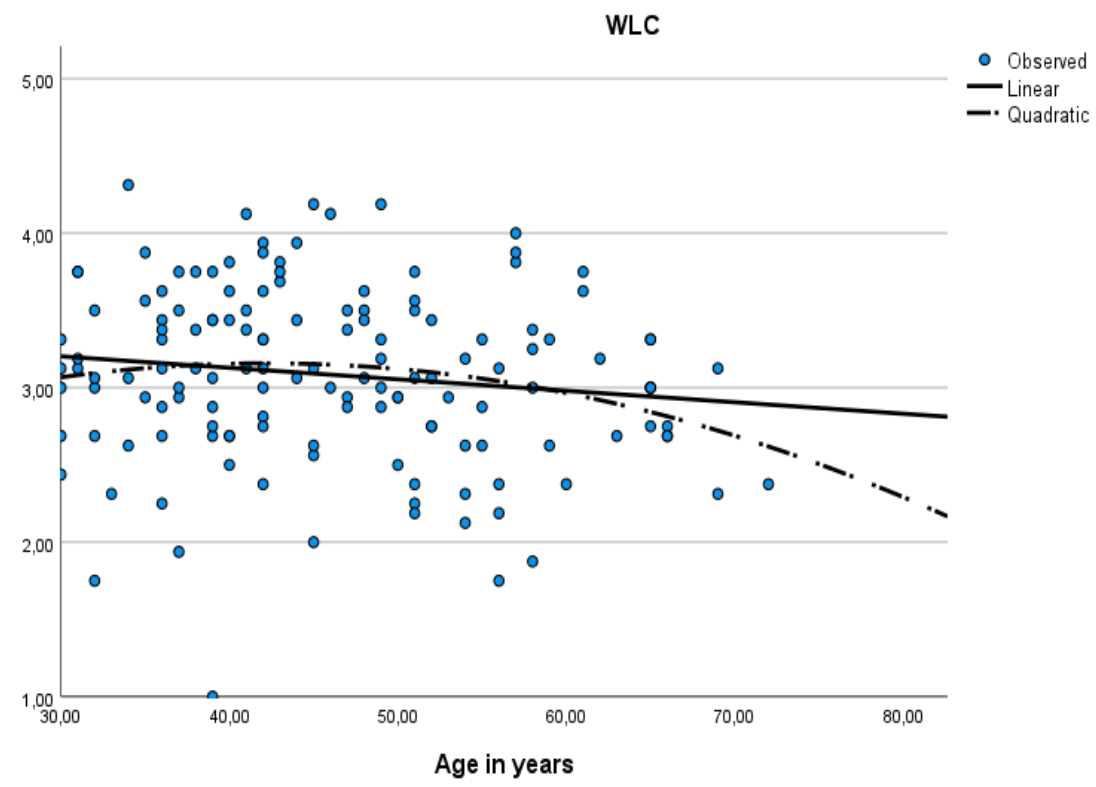

Figure 1. Graphic display of the curvilinearity test Note. Authors' calculations. 
Table 2 and Figure 1 show curvilinearity in the relationship between age in years and work-life conflict. The negative value of the quadratic value coefficient shows a downward concave curve, which confirms curvilinearity and can be interpreted as: the older one is, the less work-life conflict is present the drop begins after 51 years of age.

\section{CONCLUSION}

One of the most important social phenomena is the aging of the population and the extension of working life. Many authors have highlighted the link between gender and the work-life conflict, but few researchers have investigated how workers experience and manage the conflict between work and private life throughout their lives. The current study examined the conflict between work and family life for people aged 30 to 72 years, focusing on explanations of how the conflict between work and personal life changes with age.

The results show curvilinearity in the relationship between age in years and work-life conflict. The negative value of the quadratic value coefficient shows a downward concave curve, which confirms curvilinearity and can be interpreted as: the older one is, the less work-life conflict is present - the drop begins after 51 years of age.

For further research, we propose investigating the effects of the determinants that were omitted or, in other words, not considered in our study. To arrive at interpretations of the results, we should first analyze the limitations of this research. The study focused mainly on how age affects the conflict between work and private life of university lecturers. Simultaneously, some other demographic factors (e.g., number of pre-school children, marital status, gender, education) or other determinants were not considered, and other factors play a role in achieving lower work/private life conflicts.

The results of this study can be used for further research as well as in practice. The theoretical contribution to the existing research of work-life conflict and the practical in the results presented is that the relationships are also present in university lecturers.

People who work in a family-friendly work environment that supports the reduction of conflicts between work and family will be more satisfied with their work and vice versa (Zhao, Qu \& Ghiselli, 2011). In addition, research findings (Goh, Ilies \& Wilson, 2015; Turliuc \& Buliga, 2014) also suggest that conflicts between work and family have a significant impact on the life satisfaction of individuals. 
Work organizations can make a significant contribution to reducing work-life conflicts and consider the specific characteristics of the employee in terms of age. A healthy working environment in which the individual feels comfortable and they are respected, both as an employee and as a person with personal life. Companies want satisfied employees because they are more committed to the organization, more engaged and more productive.

\section{REFERENCES}

Brough, P., Timms, C., O'Driscoll, M. P., Kalliath, T., Oi-Ling Siu, Sit, S. \& Lo, D. (2014). Work-life balance: a longitudinal evaluation of a new measure across Australia and New Zealand workers. The International Journal of Human Resource Management, 25(19), 2724-2744.

Bohen, H. H., \& Viveros-Long, A. (1981). Balancing jobs and family life. Philadelphia: Temple University Press.

Cooklin, A. R., Dinh, H., Strazdins, L., Westrupp, E., Leach, L. S., \& Nicholson, J. M. (2016) Change and stability in work-family conflict and mothers' and fathers' mental health: Longitudinal evidence from an Australian cohort. Social Science \& Medicine, 155(2016), 24-34.

Dartey-Baah, K. (2015) Work-family Conflict, Demographic Characteristics and Job Satisfaction among Ghanaian Corporate Leaders. International Journal of Business, 20(4), 291-307.

Devi, K. R., \& Rani, S. S. (2016). The Impact of Organizational Role Stress and Work-Family Conflict: Diagnosis Sources of Difficulty at Work Place and Job Satisfaction among Women in I.T. Sector, Chennai, Tamil Nadu. Procedia - Social and Behavioral Sciences, 219, 214 - 220.

Erdamar, G., \& Demirel, H. (2014) Investigation of work-family, familywork conflict of the teachers. Procedia - Social and Behavioral Sciences, 116(2014), $4919-4924$.

Frone, M. R., Russell, M., \& Cooper, M. L. (1992). Antecedents and outcomes of work-family conflict: Testing a model of the work-family interface. Journal of Applied Psychology, 77(1), 65-78.

Goff, S. J., Mount M. K., \& Jamison, R. L. (1990). Employer supported child care, work/family conflict, and absenteeism: A field study. Personnel Psychology, 43(4), 793-809.

Goh, Z., Ilies, R., \& Wilson, K. S. (2015) Supportive supervisors improve employees' daily lives: The role supervisors play in the impact of daily 
workload on life satisfaction via work-family conflict. Journal of Vocational Behavior, 89(2015), 65-73.

Greenhaus, J. H., \& Beutell, N. J. (1985) Sources of Conflict between Work and Family Roles. The Academy of Management Review, 10(1), 76-88.

Griggs T. L., \& Casper W. J., \& Eby L.T. (2013). Work, family and community support as predictors of work-family conflict: A study of lowincome workers. Journal of Vocational Behavior, 82, 59-68.

Haar, J. M (2009). An international perspective on work-family. Community. Work \& Family, 12(3), 275-277.

Huffman, A., Culbertson, S. S., Henning, J. B., \& Goh, A. (2013). Workfamily conflict across the lifespan. Journal of Managerial Psychology, 28(7/8), 761-780.

Jiang, H., \& Shen, H. (2015). Conflict? What work-life conflict? A national study of future public relations practitioners. Public Relations Review, $41,132-134$.

Karabay, M. E., Akyüz, B., \& Elçi, M. (2016). Effects of Family-Work Conflict, Locus of Control, Self Confidence and Extraversion Personality on Employee Work Stress. Procedia - Social and Behavioral Sciences, 235, 269 280.

Mauno, S., Ruokolainen, M., \& Kinnunen, U. (2015). Work-family conflict and enrichment from the perspective of psychosocial resources: Comparing Finnish healthcare workers. Applied Ergonomics, 48, 86-94.

Michel, J. S., Kotrba, L. M., Mitchelson, J. K., Clark, M. A., \& Baltes, B. B. (2011). Antecedents of work-family conflict: A meta-analytic review. Journal of Organizational Behavior, 32, 689-725.

Minnotte, K. L., Gravelle, M., \& Minnotte, M. C. (2013). Workplace characteristics, work-to-life conflict, and psychological distress among medical workers. The Social Science Journal, 50(4), 408-417.

Netemeyer, R. G., Boles, J. S., \& McMurrian, R. (1996) Development and Validation of Work-Family Conflict and Family-Work Conflict Scales. Journal of Applied Psychology, 81(4) 400-410.

Oshio, T., Inoue, A., \& Tsutsumi, A. (2017). Does work to family conflict really matter for health? Cross-sectional, prospective cohort and fixedeffects analyses. Social Science \& Medicine, 175, 36-42. 
Qu, H., \& Zhao, X. (2012). Employees' work-family conflict moderating life and job satisfaction. Journal of Business Research, 65, 22-28.

Ryan, B., Ma, E., Hsiao, A., \& Ku, M. (2015). The work-family conflict of university foodservice managers: An exploratory study of its antecedents and consequences. Journal of Hospitality and Tourism Management, 22, 10-18.

Sav, A., Harris, N., \& Sebar, B. (2013). Work-life conflict and facilitation among Australian Muslim men, Equality, Diversity and Inclusion. An International Journal, 32(7), 671-687.

Shen, B., McCaughtry, N., Martin, J., \& Garn, A. C. (2015). The Relationship Between Teacher Burnout and Student Motivation. British Journal of Educational Psychology, 85(4), 519-532.

Turliac, M. B., \& Buliga, D. (2014). Cognitions And Work-Family Interactions: New Research Directions In Conflict And Facilitation. Procedia Social and Behavioral Sciences, 140, 86 - 91.

Wan Rashid, W. E., Sahari Nordin, M., Omar, A., \& Ismail, I. (2012). Work/Family Conflict: The Link between Self-Esteem and Satisfaction Outcomes. Procedia - Social and Behavioral Sciences, 65(3), 564-569.

Zhao, X., Qu, H., \& Ghiselli, R. (2011). Examining the relationship of work-family conflict to job and life satisfaction: a case of hotel sales managers. International Journal of Hospitality Management, 30(1), 46-54.

Delivered: 17.11.2020. Accepted: 04.02.2021. 